\title{
Morphogenesis of the Node of Ranvier: Co-Clusters of Ankyrin and Ankyrin-Binding Integral Proteins Define Early Developmental Intermediates
}

\author{
Stephen Lambert, Jonathan Q. Davis, and Vann Bennett \\ Department of Cell Biology and the Howard Hughes Medical Institute, Duke University Medical Center, Durham, \\ North Carolina 27710
}

\begin{abstract}
Ankyrin $_{\mathrm{G}}$ 480/270 kDa and three ankyrin-binding integral membrane proteins (neurofascin, $\mathrm{NrCAM}$, and the voltagedependent sodium channel) colocalize within a specialized domain of the spectrin-actin network found at axonal segments of nodes of Ranvier in myelinated axons. Before myelination in embryonic nerves, ankyrin ${ }_{\mathrm{G}} 480 / 270 \mathrm{kDa}$ and the related ankyrin isoform ankyrin $\mathrm{B}_{\mathrm{B}} 440 \mathrm{kDa}$ are co-expressed along with NrCAM in an abundant, continuous distribution along the length of axons. This study has resolved intermediate stages in the developmental transition from a continuous distribution of ankyrin $_{\mathrm{G}} 480 / 270 \mathrm{kDa}$ in all axons to a highly polarized localization at the node of Ranvier in the developing rat sciatic nerve. The first detected event is formation of clusters containing the cell adhesion molecules neurofascin and NrCAM at sites independent of myelin-associated glycoprotein (MAG)-staining Schwann cell processes. Subsequent steps involve recruitment of ankyrin a $480 / 270 \mathrm{kDa}$ and the voltage-dependent sodium
\end{abstract}

channel to cluster sites containing cell adhesion molecules, and elaboration of MAG-staining Schwann cell processes adjacent to these cluster sites. Formation of the mature node of Ranvier results from the fusion of asynchronously formed pairs of clusters associated with MAG-positive Schwann cells flanking the site of presumed node formation. Studies with the hypomyelinating mutant mouse trembler demonstrate that the elaboration of compact myelin is not required for the formation of these clustered nodal intermediates. Clustering of neurofascin and NrCAM precedes redistribution of ankyrin ${ }_{\mathrm{G}} 480 / 270 \mathrm{kDa}$ and the voltage-dependent sodium channel, suggesting that the adhesion molecules define the initial site for subsequent assembly of ankyrin and the voltage-dependent sodium channel.

Key words: node of Ranvier; cell adhesion molecules; ankyrin; voltage-dependent sodium channel; myelination; trembler mutant
The localization of ion channels, in particular the voltagedependent sodium channel, to gaps in the myelin sheath known as the nodes of Ranvier, is crucial to the propagation of saltatory action potentials in myelinated nerves. In the internodal axonal membrane, the voltage-dependent sodium channel is found at concentrations of 20-25 channels $/ \mu \mathrm{m}^{2}$, compared with concentrations ranging from 1000 channels $/ \mu \mathrm{m}^{2}$ (Shrager, 1989) to 12,000 channels $/ \mu \mathrm{m}^{2}$ (Ritchie and Rogart, 1977) at the node of Ranvier. The asymmetric distribution of ion channels in the myelinated axon and the regular spacing of these nodes at $\sim 100$ times the axonal diameter (Rushton, 1951; Chiu, 1980) are critical for the fast conduction velocities associated with these axons and represent an interesting problem in cell polarity and membrane differentiation.

A clue as to the molecular organization of the node comes from observations that the voltage-dependent sodium channel copurifies and binds with high affinity to the peripheral membrane protein ankyrin (Srinivasan et al., 1988). In addition, other ankyrin-binding proteins are also localized at the node, including isoforms of neurofascin and NrCAM (Davis et al., 1993, 1996),

Received March 20, 1997; revised May 29, 1997; accepted July 9, 1997.

This work was supported by the Howard Hughes Medical Institute and a grant from National Institutes of Health (DK29808). Zhang Xu is gratefully acknowledged for the preparation of the chicken anti-ankyrin ${ }_{\mathrm{G}}$ common "tail" antibody.

Correspondence should be addressed to Dr. Lambert at his present address: Worcester Foundation for Biomedical Research, 222 Maple Avenue, Shrewsbury, MA 01545.

Copyright (C) 1997 Society for Neuroscience $\quad 0270-6474 / 97 / 177025-12 \$ 05.00 / 0$ ankyrin-binding cell adhesion molecules related to L1 (for review, see Hortsch, 1996). Ankyrin itself is localized at the 1- to 2- $\mu$ m-size nodal axonal plasma membrane (Kordeli et al., 1990) and is a component of the electron dense undercoating observed beneath the nodal membrane (Peters, 1966; Ichimura and Ellisman, 1991). Ankyrins are a family of spectrin-binding proteins that associate with diverse integral proteins, including ion channels, calcium-release channels, and cell adhesion molecules, and link these proteins to the spectrin-based membrane skeleton (for review, see Bennett and Gilligan, 1993; Lambert and Bennett, 1993). The isoforms of ankyrin localized at nodes of Ranvier have recently been identified as 480 and $270 \mathrm{kDa}$ alternatively spliced variants of the ankyrin $_{\mathrm{G}}$ gene (Kordeli et al., 1995). These ankyrin isoforms are concentrated at axon initial segments and nodes of Ranvier in the adult rat CNS and PNS (Kordeli et al., 1995), and to our knowledge they represent the first unique cytoplasmic components of the node to be identified. Nodal ankyrin isoforms are distinguished by a $46 \mathrm{kDa}$ serinethreonine-rich domain glycosylated with O-GlucNAc residues (Zhang and Bennett, 1996), and like other ankyrins associate with integral proteins through a membrane-binding domain comprising 24 ANK repeats. Biochemical studies of this domain (Michaely and Bennett, 1995a,b) suggest that ankyrin could facilitate lateral homo- and heterocomplexes between integral membrane proteins.

The absence of suitable molecular markers has hindered elucidation of the role of components of the electron-dense undercoating in the differentiation of the nodal membrane. This study 
examines the distribution of ankyrin $_{\mathrm{G}} 480 / 270 \mathrm{kDa}$, the voltagedependent sodium channel, neurofascin, and NrCAM during development in the myelinating sciatic nerve. Ankyrin ${ }_{\mathrm{G}} 480 / 270$ $\mathrm{kDa}$ polypeptides are highly expressed in a uniform distribution along premyelinated axons at embryonic day 16 and redistribute to clusters adjacent to the ends of Schwann cells in early postnatal development. The voltage-dependent sodium channel also is localized in clusters, as reported recently in developing and regenerating nerves (Dugandzija-Novakovic et al., 1995; Vabnick et al., 1996), and is colocalized at these sites with ankyrin $_{\mathrm{G}} 480 / 270 \mathrm{kDa}$ as well as neurofascin and $\mathrm{NrCAM}$. Clustering of neurofascin and NrCAM precedes redistribution of ankyrin $_{\mathrm{G}} 480 / 270 \mathrm{kDa}$ and the voltage-dependent sodium channel and also precedes early events in myelin formation, as determined by the expression of myelin-associated glycoprotein (MAG). These results and the finding of clusters in hypomyelinating mice suggest that axonal adhesion molecules define the initial site for subsequent assembly of ankyrin and the voltage-dependent sodium channel into the differentiating nodal axonal membrane and that these events are independent of the formation of compact myelin.

\section{MATERIALS AND METHODS}

Preparation of antibodies. Antibodies against the common tail region of rat ankyrin ${ }_{\mathrm{G}} 480$ and $270 \mathrm{kDa}$ were raised in chickens for double-labeling studies. Chickens were immunized with a purified recombinant polypeptide corresponding to the rat equivalent of residues 1821-2337 of the human $\operatorname{ankyrin}_{\mathrm{G}}$ sequence. This polypeptide was produced by expression in bacteria of the rat cDNA using the pGemex expression vector (Promega, Madison, WI), resulting in a fusion product with the viral gene 10 protein. Antibodies were initially purified from chicken egg yolk using an Egg Yolk Purification Kit (Pharmacia Biotech, Piscataway, NJ) and affinity-purified against purified recombinant polypeptide immobilized on Sepharose CL-6B (Pharmacia) after the previous depletion of antibodies using immobilized gene 10 polypeptide. Antibodies against neurofascin and $\mathrm{NrCAM}$ were generated in rabbits using purified recombinant FNIII domains (residues 581-1020 of rat neurofascin and residues 583-1018 of rat NrCAM) from these molecules as antigens. These recombinant domains were prepared in bacteria as above. Affinitypurified antibodies were then prepared from sera by purification against immobilized native $186 \mathrm{kDa}$ neurofascin and NrCAM. Native proteins were purified from detergent extracts of adult rat brain membranes as described previously (Davis et al., 1993). Antibodies against neurofascin did not cross-react with purified native NrCAM by immunoblot analysis and vice versa (Davis et al., 1996). Antibodies against the voltagedependent sodium channel were prepared by immunization of rabbits with four multiple-antigen peptides corresponding to residues $440-453$, $482-492,547-561$, and 582-600 of the $\alpha \mathrm{I}$ subunit (Noda et al., 1986). These sequences are relatively conserved in the three $\alpha$ subunits expressed in the rat brain and are in an area of the molecule proposed to be a cytoplasmic linker between the I and II transmembrane poreforming units. An area of the rat $\alpha \mathrm{I}$ subunit (corresponding to nucleotides 1292-2215) encompassing these peptide sequences was cloned from a rat brain library using PCR. The cDNA was subcloned into the pGemex expression vector, expressed in bacteria, and the purified recombinant polypeptide was immobilized and used in the affinity purification of the peptide antisera, as described above. Preparation of affinity-purified antibodies against brain spectrin has been described previously (Davis and Bennett, 1983). Antibodies against the MAG were purchased from Boehringer Mannheim (Indianapolis, IN).

Gel electrophoresis and immunoblot analysis. Gel samples of adult rat brain membranes were prepared as described previously (Kordeli et al., 1995) and fractionated on 3.5-17\% exponential gradient gels before transfer to nitrocellulose (Davis and Bennett, 1983). Bound antibodies were visualized using ${ }^{125}$ I-labeled protein A and autoradiography (Davis and Bennett, 1983).

Immunocytochemical procedures. Immunocytochemistry of frozen sections from rodent sciatic nerves was performed essentially as described (Kordeli et al., 1990). Animals of various ages were killed, and the sciatic nerves were removed by dissection. Sciatic nerves were immediately fixed in $2 \%$ paraformaldehyde either overnight at $4^{\circ} \mathrm{C}$ or for $3 \mathrm{hr}$ at $4^{\circ} \mathrm{C}$ (for experiments involving antibodies against the voltage-dependent sodium

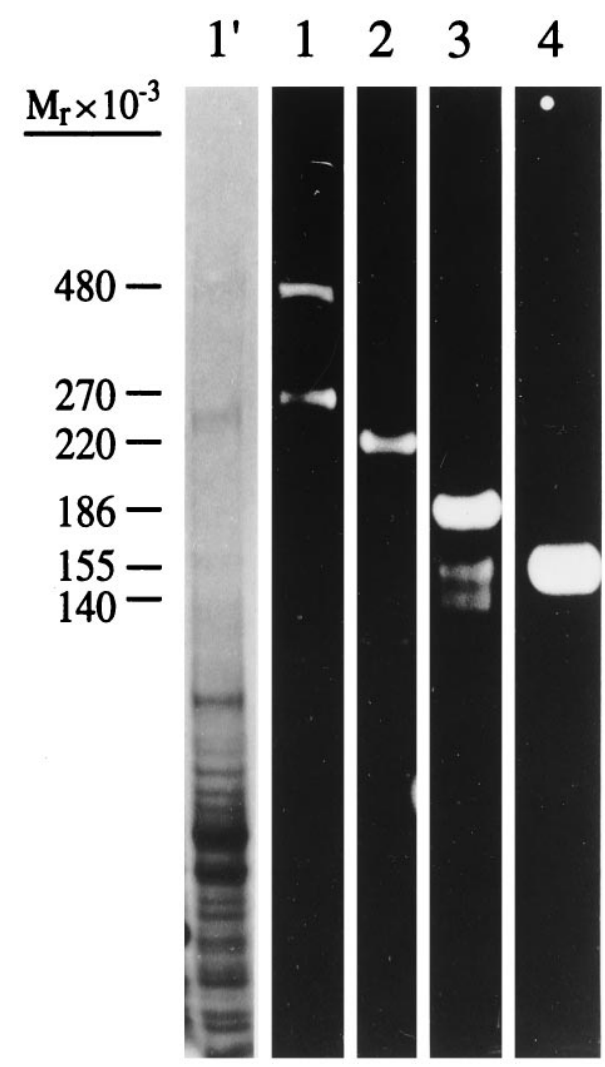

Figure 1. Immunoblot analysis of adult total rat brain membranes with antibodies against (1) ankyrin $_{\mathrm{G}} 480 / 270 \mathrm{kDa}$, (2) voltage-dependent sodium channel, (3) neurofascin, and (4) NrCAM. Lane 1' shows the brain membrane preparation stained with Coomassie blue.

channel) before cryopreservation in sucrose and freezing in liquid nitrogen-cooled isopentane. Primary antibodies bound on $4 \mu \mathrm{m}$ cryosections were visualized with rhodamine-labeled goat anti-rabbit Ig (Cappel, West Chester, PA) alone or in combination with fluorescein-labeled mouse monoclonal anti-chicken Ig (clone CH31, Sigma, St. Louis, MO) in double-labeling experiments. Confocal images were collected on a Zeiss LSM 410 confocal microscope, and final figures were prepared using Adobe Photoshop.

\section{RESULTS}

\section{Characterization of antibodies against ankyrin a $_{\mathrm{G}} 480$ / $270 \mathrm{kDa}$, the voltage-dependent sodium channel, neurofascin, and NrCAM}

Figure 1 shows an immunoblot analysis of total adult rat brain membranes (lane $1^{\prime}$ ) probed with antibodies raised against anky$\operatorname{rin}_{\mathrm{G}} 480 / 270 \mathrm{kDa}$ and the following ankyrin-binding proteins: voltage-dependent sodium channel (lane 2), neurofascin (lane 3), and NrCAM (lane 4). Chicken antibodies against the common "tail" domain of ankyrin $_{\mathrm{G}} 480 / 270 \mathrm{kDa}$ recognize two polypeptides of 480 and $270 \mathrm{kDa}$ as predicted. Ankyrin $\mathrm{G}_{\mathrm{G}} 270 \mathrm{kDa}$ arises from ankyrin $_{\mathrm{G}} 480 \mathrm{kDa}$ by alternative mRNA processing between nucleotides 7202 and 12446 of the ankyrin $_{\mathrm{G}}$ cDNA published sequence, removing 1748 amino acids from the ankyrin ${ }_{\mathrm{G}}$ "tail" domain (our unpublished data). Antibodies raised against the deleted sequence specific to ankyrin $_{\mathrm{G}} 480 \mathrm{kDa}$ recognize nodes of Ranvier in adult sciatic nerve (Zhang and Bennett, 1996) as well as nodal intermediates in myelinating axons (not shown). Expression of ankyrin $_{\mathrm{G}} 480 \mathrm{kDa}$ precedes that of ankyrin $_{\mathrm{G}} 270$ $\mathrm{kDa}$, which is expressed only after day 10 in the developing nervous system. Antibodies raised against the voltage-dependent 


\section{spectrin}

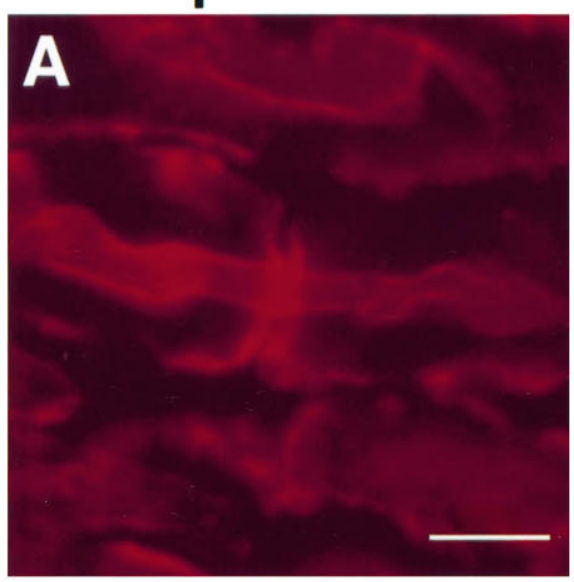

$\operatorname{ankyrin}_{G}$

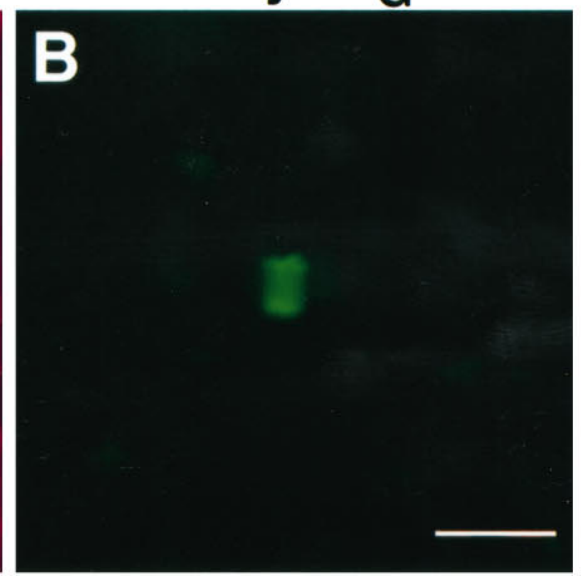

composite

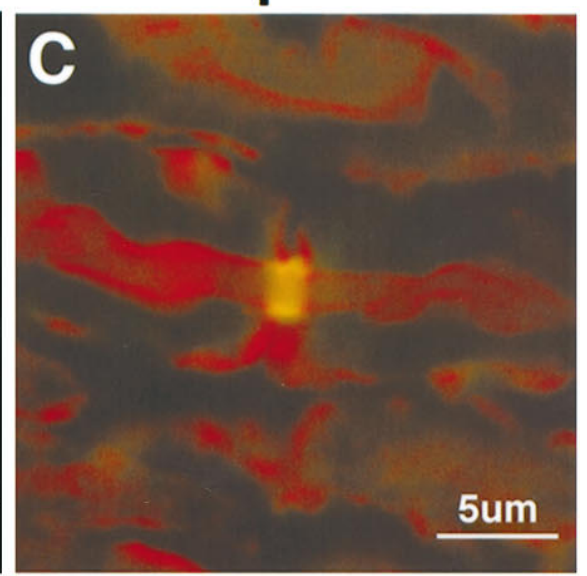

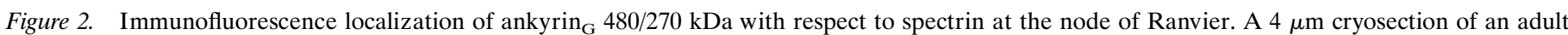

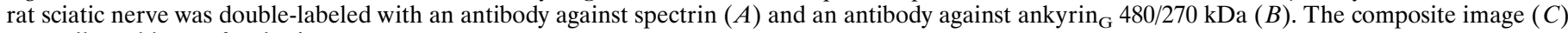
was collected by confocal microscopy.

sodium channel show a single band representing the $260 \mathrm{kDa} \alpha$ subunit, which migrates at $220 \mathrm{kDa}$ in a continuous electrophoretic buffer system (Srinivasan et al., 1988). These antibodies also strongly label nodes of Ranvier in adult sciatic nerve (Davis et al., 1996), confirming earlier antibody localization of the voltage-dependent sodium channel to the node (Ellisman and Levinson, 1982). Antibodies against FNIII domains 1-4 of neurofascin and NrCAM show three polypeptides of 186, 155, and $140 \mathrm{kDa}$ for neurofascin as described (Davis et al., 1996) and a single polypeptide of $150 \mathrm{kDa}$ for NrCAM. The three neurofascin polypeptides are alternatively spliced products of the rat neurofascin gene (Davis et al., 1996), whereas the $150 \mathrm{kDa}$ NrCAM polypeptide represents the extracellular domain of NrCAM (Kayyem et al., 1992; Davis and Bennett, 1994).

\section{Ankyrin $_{G}$ 480/270 kDa defines a specialized domain within the spectrin-actin network at nodal axon segments of adult nodes of Ranvier}

Localization of ankyrin G $_{\mathrm{G}}$ with respect to spectrin was examined in the adult sciatic nerve by confocal microscopy using doublelabeling with rabbit antibody against spectrin and a chicken antibody against ankyrin $_{\mathrm{G}} 480 / 270 \mathrm{kDa}$ (Fig. 2). Spectrin (Fig. 2A) stains continuously along the axon (Trapp et al., 1989), including the nodal and paranodal areas, characterized by a reduction in axonal caliber. Spectrin staining also occurs in the cytoplasmic process of the Schwann cell on the outside edge of the myelin sheath. Antibody against ankyrin $_{\mathrm{G}} 480 / 270 \mathrm{kDa}$ (Fig. 2B), in contrast, is localized to a $1-2 \mu \mathrm{m}$ zone comprising the nodal membrane, in agreement with initial observations of ankyrin ${ }_{\mathrm{G}}$ staining (Kordeli et al., 1995). The ankyrin binding proteins NrCAM, neurofascin, and the voltage-dependent sodium channel also are colocalized with ankyrin $_{\mathrm{G}} 480 / 270 \mathrm{kDa}$ at the adult node of Ranvier (Davis et al., 1996).

\section{Ankyrin $_{\mathrm{G}}$ 480/270 kDa and ankyrin $440 \mathrm{kDa}$ are co-expressed in an abundant, continuous distribution along axons before myelination}

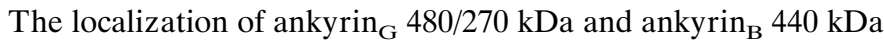
were examined in premyelinated axons of the developing rat nervous system. Extensive immunostaining for both ankyrins was observed in axons of both the CNS and PNS in the embryonic day
16 rat. Figure 3 shows the colocalization (arrows) of ankyrin G $_{\mathrm{G}}$ $480 / 270 \mathrm{kDa}(B, D, F)$ with spectrin $(A), \operatorname{NrCAM}(C)$, and the ankyrin $_{\mathrm{B}} 440 \mathrm{kDa}$ molecule $(E)$ in axons and bundles of axons emanating from dorsal root ganglia. Ankyrin ${ }_{\mathrm{G}}$ 480/270 kDa and ankyrin $_{\mathrm{B}} 440 \mathrm{kDa}$ as well as the ankyrin-binding proteins were abundantly expressed in these axons and localized continuously along their length. Only faint levels of neurofascin immunostaining were observed, confirming observations that suggest a predominantly postnatal expression for this protein in mammals (Davis et al., 1993; Mocosco and Sanes, 1995). No staining was detectable in these axons using antibodies to the voltagedependent sodium channel.

These results demonstrate a major difference between the distribution of axonal ankyrins in early development and in adult nerve axons. Ankyrin $440 \mathrm{kDa}$, which apparently is present in some axons before myelination, disappears from myelinated axons and is present in unmyelinated axons in the adult CNS (Kunimoto et al., 1991; Chan et al., 1993). Ankyrin ${ }_{\mathrm{G}}$ 480/270 kDa is co-expressed with ankyrin ${ }_{\mathrm{B}} 440 \mathrm{kDa}$ in embryonic nerve, but in adults it is absent from unmyelinated axons as well as regions of myelinated axons in contact with myelin (Kordeli et al., 1995) (Fig. 2).

\section{Ankyrin $_{\mathrm{G}}$ 480/270 kDa redistributes to clusters containing $\mathrm{Na}$ channel, neurofascin, and NrCAM localized at sites adjacent to MAG-staining processes of Schwann cells during myelination of peripheral nerve}

The transition from a continuous distribution of ankyrin $_{\mathrm{G}} 480$ / $270 \mathrm{kDa}$ in axons to a highly polarized localization at the node of Ranvier with low expression in unmyelinated axons in the adult was studied in myelinating sciatic nerves during early postnatal development of rats. Myelination in the sciatic nerve occurs between postnatal days 2 and 13, and it occurs at different rates and times depending on the axon. This heterogeneity allows visualization of axons in various stages of myelination in a single section of postnatal tissue, but it also presents a problem in distinguishing early stages in myelination. Expression of the MAG provided a marker for the onset of myelination and for Schwann cell processes that contact axons. MAG is expressed by 

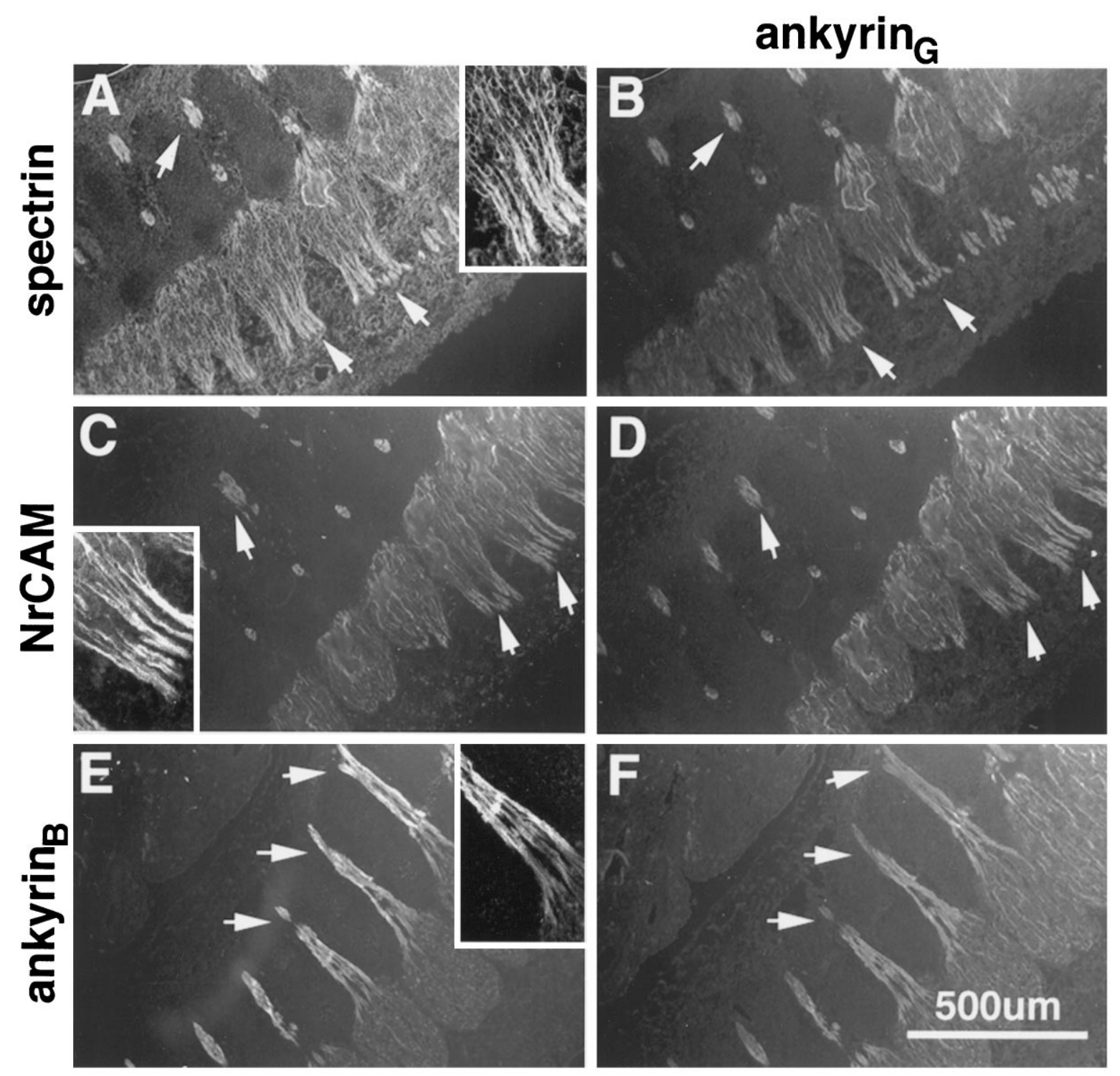

Figure 3. Colocalization of ankyrin $_{\mathrm{G}} 480 / 270 \mathrm{kDa}$, spectrin, $\mathrm{NrCAM}$, and ankyrin $\mathrm{B}_{\mathrm{B}} 440 \mathrm{kDa}$ in dorsal root axons of the embryonic day 16 rat. Cryosections $(4 \mu \mathrm{m})$ of the dorsal roots from an embryonic day 16 rat were double-labeled with antibodies to ankyrin ${ }_{\mathrm{G}} 480 / 270 \mathrm{kDa}(B, D, F)$ and spectrin $(A), \operatorname{NrCAM}(C)$, or ankyrin $440 \mathrm{kDa}(E)$. Arrows indicate the staining of axons or bundles of axons emanating from the dorsal roots. Insets show a single bundle of axons at $2 \times$ higher magnification.

Schwann cells at $\sim 1.5$ turns of the Schwann cell around the axon and is initially localized to the periaxonal interface (Martini and Shachner, 1986). As myelination progresses, MAG becomes increasingly localized to areas of uncompacted myelin such as the paranodal loops adjacent to the nodal axon segment in adult nodes of Ranvier (Trapp et al., 1989).

Figure 4 shows the localization of ankyrin $_{\mathrm{G}} 480 / 270 \mathrm{kDa}(A, E)$ with respect to MAG as a marker for Schwann cell processes $(C$, $D$ ) in the 2-d-old rat sciatic nerve. Although ankyrin $_{\mathrm{G}} 480 / 270$ $\mathrm{kDa}$ was still localized predominantly along the length of axons, 1- to 2- $\mu \mathrm{m}$-size clusters of staining (arrowheads) were observed. Clusters were also occasionally observed in pairs $\sim 5-10 \mu \mathrm{m}$ apart. Ankyrin clusters were localized to gaps between MAG staining, presumably representing sites of node formation between myelinating Schwann cells. Clusters were also observed at the ends of MAG-positive fibers. Formation of ankyrin ${ }_{\mathrm{G}} 480 / 270$ $\mathrm{kDa}$ clusters correlated with the onset of myelination, as indicated by the expression of MAG. No ankyrin $_{\mathrm{G}} 480 / 270 \mathrm{kDa}$ clusters were observed in areas of the sciatic nerve with little or no apparent MAG staining.

The localization of ankyrin $_{B} 440 \mathrm{kDa}$ with respect to $\mathrm{MAG}$ was also examined in the 2-d-old rat sciatic nerve. Although ankyrin $_{\mathrm{B}} 440 \mathrm{kDa}$ colocalized with ankyrin $_{\mathrm{G}} 480 / 270 \mathrm{kDa}$ in premyelinated axons of the embryonic nervous system (Fig. $3 E, F)$, it is expressed at much lower concentrations in myelinating areas (i.e., MAG-positive areas) of the 2-d-old sciatic nerve (Fig. $4 B, F$ ). Figure 5 shows the localization of ankyrin $_{\mathrm{B}} 440 \mathrm{kDa}$ $(A)$ with respect to ankyrin $_{\mathrm{G}} 480 / 270 \mathrm{kDa}(B)$ in the 2 -d-old sciatic nerve and indicates that these molecules colocalize in axons lacking ankyrin ${ }_{\mathrm{G}} 480 / 270 \mathrm{kDa}$ clusters. Ankyrin ${ }_{\mathrm{B}} 440 \mathrm{kDa}$ also is colocalized with ankyrin G $_{\mathrm{G}} 480 / 270 \mathrm{kDa}$ in clusters, but it is not concentrated to the same degree as ankyrin $_{\mathrm{G}} 480 / 270 \mathrm{kDa}$. Ankyrin $_{\mathrm{B}} 440 \mathrm{kDa}$ also is present in some but not all adult nodes of Ranvier (our unpublished data). The two ankyrins thus may 


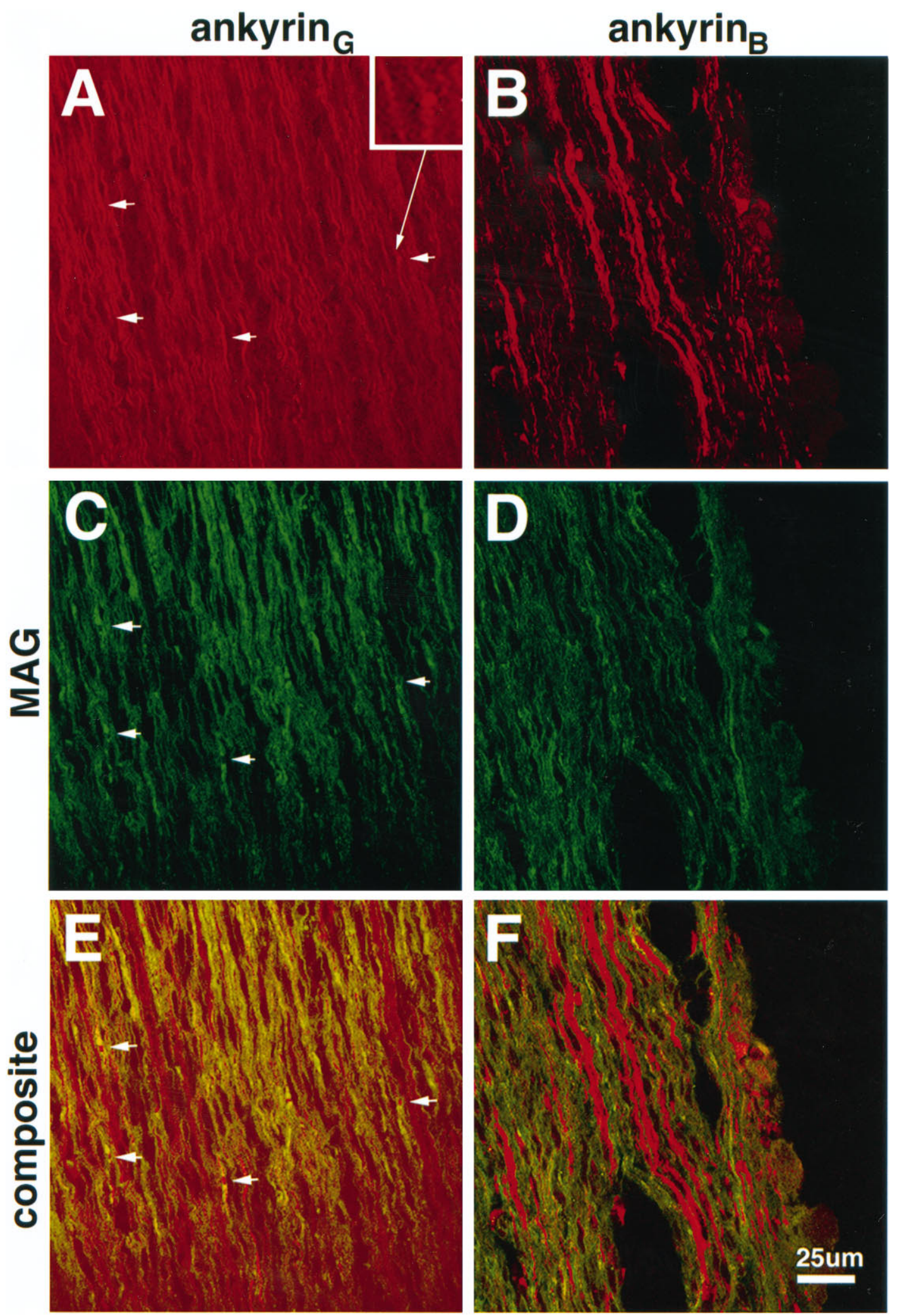

Figure 4. Localization of ankyrin ${ }_{\mathrm{G}} 480 / 270 \mathrm{kDa}$ and ankyrin $_{\mathrm{B}} 440 \mathrm{kDa}$ with respect to MAG in the 2-d-old rat sciatic nerve. Cryosections (4 $\left.\mu \mathrm{m}\right)$ of the 2-d-old rat sciatic nerve were double-labeled with antibodies to ankyrin ${ }_{\mathrm{G}} 480 / 270 \mathrm{kDa}(A), \operatorname{ankyrin}_{\mathrm{B}} 440 \mathrm{kDa}(B)$, and MAG $(C, D)$. Composite images collected by confocal microscopy are shown in $E$ and $F$. Arrows denote the position of ankyrin ${ }_{\mathrm{G}} 480 / 270 \mathrm{kDa}$ clusters. Inset shows one of these clusters at $3 \times$ higher magnification. 

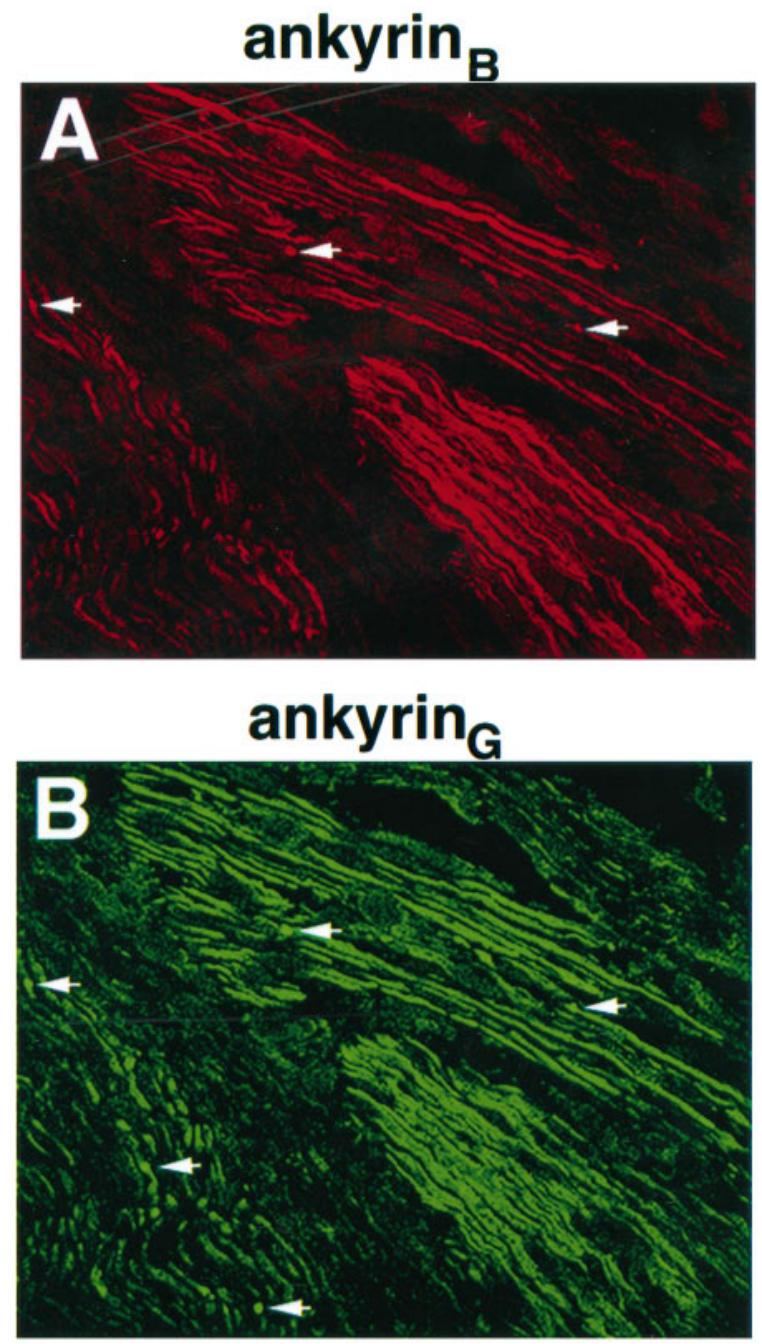

\section{composite}

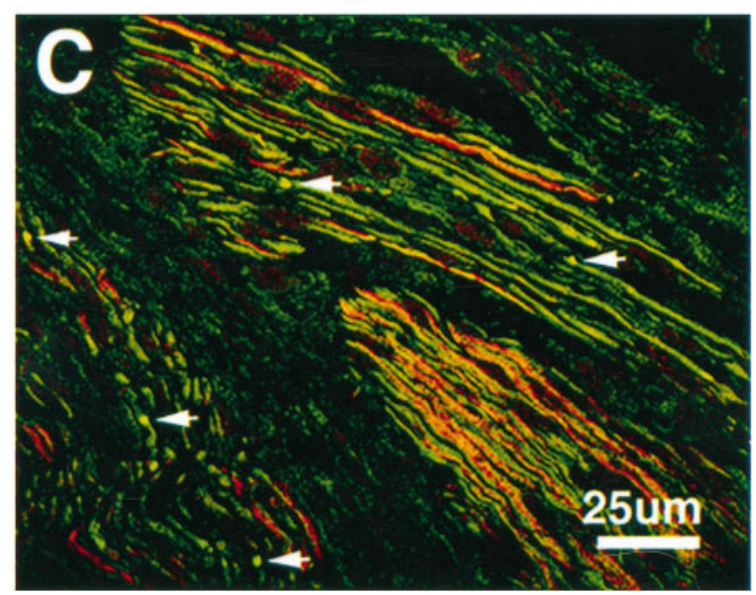

Figure 5. Colocalization of $\operatorname{ankyrin}_{\mathrm{G}} 480 / 270 \mathrm{kDa}$ and $\operatorname{ankyrin}_{\mathrm{B}} 440 \mathrm{kDa}$ in the 2-d-old rat sciatic nerve. A $4 \mu \mathrm{m}$ cryosection of the 2-d-old rat sciatic nerve was labeled with antibodies to ankyrin $_{\mathrm{B}} 440 \mathrm{kDa}(A)$ and ankyrin $_{\mathrm{G}} 480 / 270 \mathrm{kDa}(B)$. The composite confocal image is shown in $C$. Arrows denote the position of ankyrin $_{\mathrm{G}} 480 / 270 \mathrm{kDa}$ clusters.

exhibit some functional overlap. The remainder of this study will focus on ankyrin $_{\mathrm{G}} 480 / 270 \mathrm{kDa}$.

Colocalization of ankyrin G $_{\mathrm{G}} 480 / 270 \mathrm{kDa}$ and ankyrin-binding

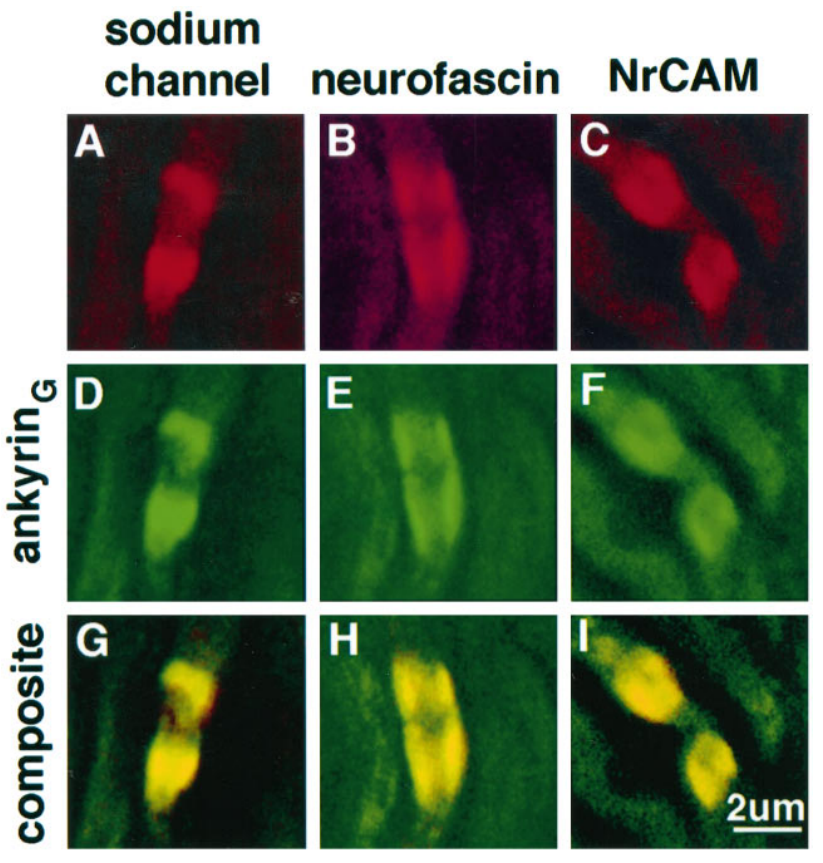

Figure 6. Co-clustering of ankyrin ${ }_{\mathrm{G}}$ and ankyrin-binding proteins in paired cluster intermediates of the 2-d-old rat sciatic nerve. Cryosections $(4 \mu \mathrm{m})$ of the 2-d-old rat sciatic nerve were double-labeled with antibodies

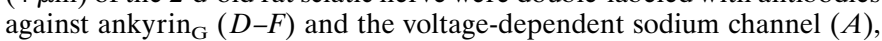
neurofascin $(B)$, or NrCAM $(C)$. Composite confocal images of individual double-cluster structures are shown in $G-I$.

proteins in developing nerve was assessed at the light level using double-labeling with respect to ankyrin $_{\mathrm{G}}$ in the 2-d-old rat sciatic

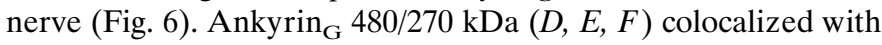
the voltage-dependent sodium channel $(G)$, neurofascin $(H)$, and $\operatorname{NrCAM}(I)$ in paired clusters. In addition, single clusters also exhibited this colocalization, and no clusters of ankyrin ${ }_{\mathrm{G}} 480 / 270$ $\mathrm{kDa}$ without ankyrin-binding proteins were observed in 94 clusters examined. Inference of the colocalization of these molecules is obviously limited to the resolution of the light microscope in these experiments and awaits further confirmation by doublelabeling immunoelectron microscopy.

The relationship of neurofascin-NrCAM clusters to MAGstaining Schwann cell processes is shown at high magnification in the 5-d-old rat sciatic nerve (Fig. 7). Neurofascin (Fig. 7A, red) is observed in paired clusters where MAG-positive fibers (green) flank both sides of the pair, as well as single clusters associated with asymmetrical MAG staining. Overlap in neurofascin and MAG staining is clearly observed (Fig. 7, arrowheads), although the highest density of neurofascin clustering did not overlap with MAG staining and was observed in front of the MAG-positive fiber. Because this antibody also stains paranodal isoforms of neurofascin in adult nodes of Ranvier (Davis et al., 1996), this result suggests that neurofascin might be playing a role in establishment of glial-axonal junctions important to the formation of the paranodal domain. Figure $7 B$ shows the localization of NrCAM (red) to both paired and single cluster intermediates. In the paired intermediate, the unequal accumulation of MAG staining (Fig. 7B, green) in the developing paranodal area associated with the left-hand cluster suggests differing levels of myelination on either side of the developing node. The NrCAM clusters clearly localize outside of MAG staining in front of the developing paranodal area, with no apparent contact with the 


\section{neurofascin}

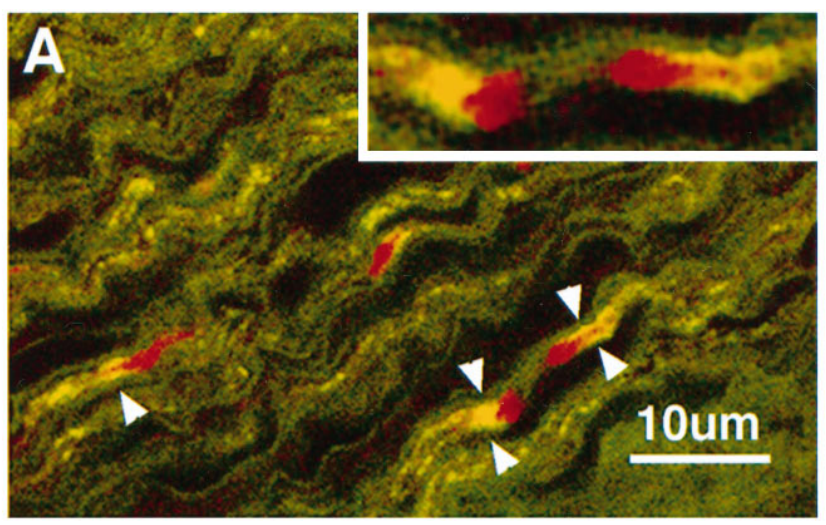

\section{NrCAM}

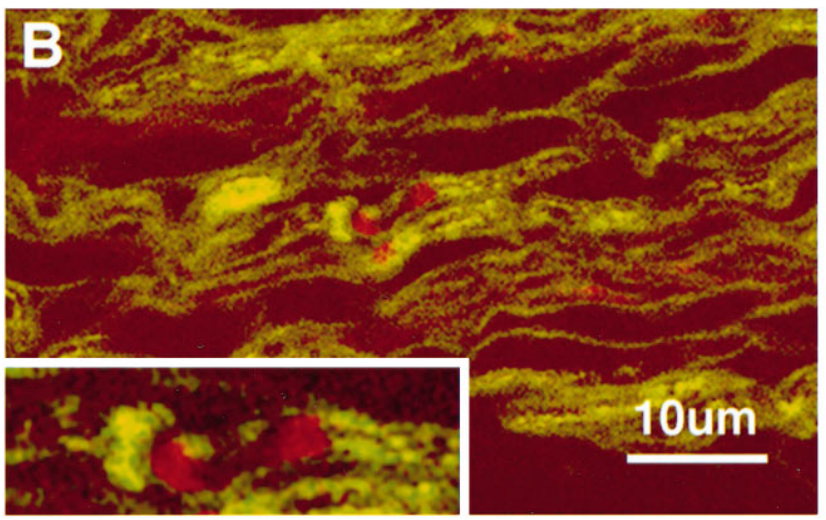

Figure 7. Immunolocalization of the ankyrin-binding cell adhesion molecules neurofascin and NrCAM with respect to MAG in the 5-d-old rat sciatic nerve. Confocal micrographs show $4 \mu \mathrm{m}$ cryosections doublelabeled with MAG (fluorescein) and neurofascin (rhodamine in $A$ ) or NrCAM (rhodamine in $B$ ). Arrowheads indicate areas of neurofascin and MAG overlap. Insets show areas of interest at $2 \times$ higher magnification.

myelinating glial cell. A localization pattern similar to that of NrCAM was observed for ankyrin ${ }_{\mathrm{G}}$ and the voltage-dependent sodium channel (data not shown).

\section{Clustering of neurofascin and NrCAM precedes redistribution of ankyrin $_{\mathrm{G}} 480 / 270 \mathrm{kDa}$ and the voltage-dependent $\mathrm{Na}$ channel}

The previous experiments demonstrate that ankyrin $_{\mathrm{G}} 480 / 270$ $\mathrm{kDa}$ and ankyrin-binding proteins concentrate in clusters localized adjacent to Schwann cell processes as an initial event in assembly of the node of Ranvier. Double-labeling experiments revealed that all clusters that contained ankyrin also had ankyrinbinding proteins (Fig. 6); however, these results do not answer the question of which protein arrives first at clusters. A careful examination of colocalization of neurofascin and NrCAM with respect to ankyrin $_{\mathrm{G}} 480 / 270 \mathrm{kDa}$ in the day 2 sciatic nerve revealed the presence of neurofascin and NrCAM clusters without concomitant clustering of ankyrin $_{\mathrm{G}} 480 / 270 \mathrm{kDa}$ (Fig. 8). In contrast, no examples were found of clustered voltage-dependent sodium channel in the absence of ankyrin (not shown). Figure 8 shows rhodamine-labeled clusters (arrows) of neurofascin $(A)$ and $\operatorname{NrCAM}(B)$ alone and double-labeled clusters of these molecules with ankyrin $_{\mathrm{G}} 480 / 270 \mathrm{kDa}$ (arrowheads). These data

\section{ankyrin $_{\mathrm{G}}$ /neurofascin}

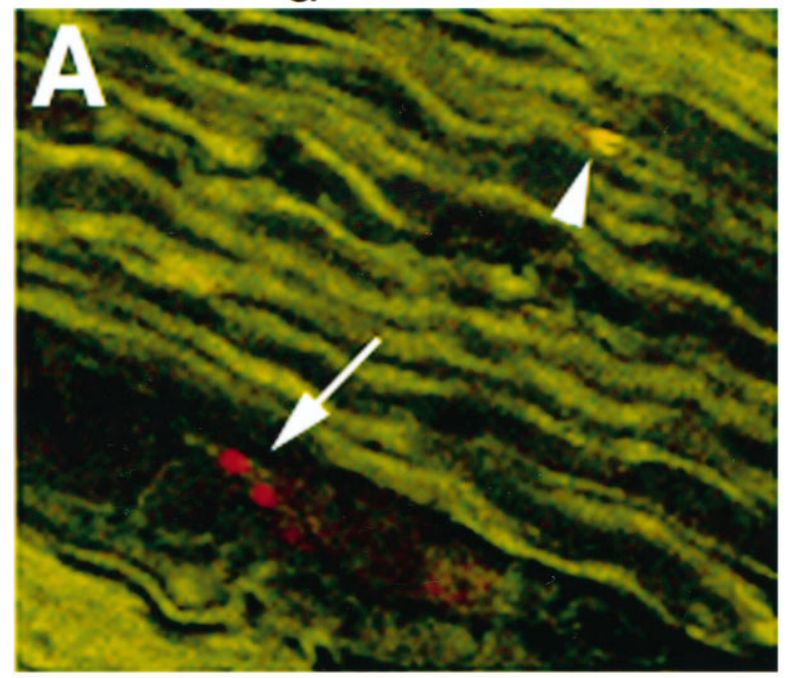

\section{ankyrin $_{\mathrm{G}}$ /NrCAM}

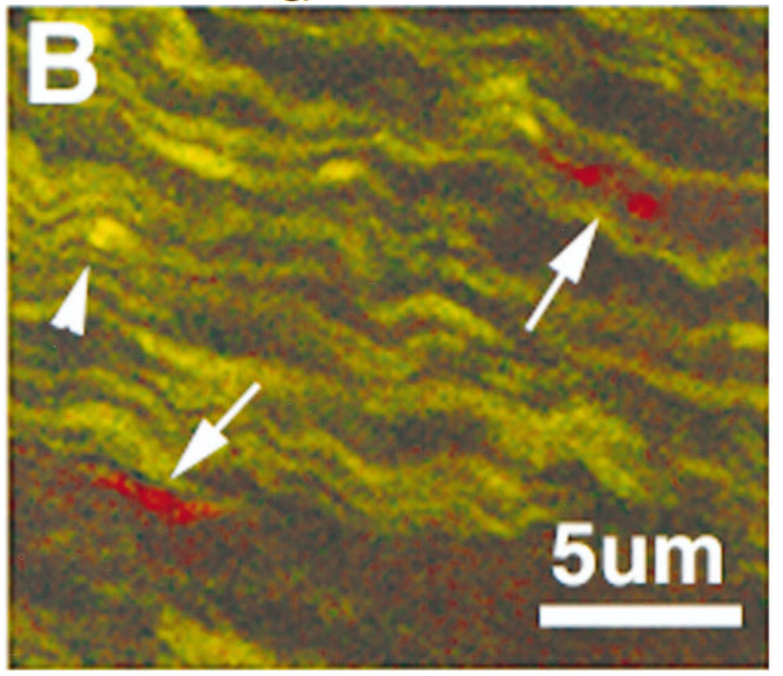

Figure 8. Colocalization of ankyrin ${ }_{\mathrm{G}} 480 / 270 \mathrm{kDa}$ (fluorescein in $A$ and $B$ ) with respect to neurofascin (rhodamine in $A$ ) and $\operatorname{NrCAM}$ (rhodamine in $B$ ) in $4 \mu \mathrm{m}$ cryosections of the 2-d-old rat sciatic nerve. Co-clusters of ankyrin $_{\mathrm{G}} 480 / 270 \mathrm{kDa}$ with neurofascin or NrCAM are denoted by arrowheads. Clusters of neurofascin or NrCAM alone are denoted by arrows.

suggest that clustering of the cell adhesion molecules neurofascin and NrCAM precedes that of ankyrin $_{\mathrm{G}} 480 / 270 \mathrm{kDa}$ and the voltage-dependent sodium channel in the myelinating sciatic nerve.

The possibility that NrCAM and neurofascin cluster before ankyrin $_{\mathrm{G}} 480 / 270 \mathrm{kDa}$ is further supported by comparison of the distribution of these molecules in the 2-d-old sciatic nerve (Fig. 9). Ankyrin ${ }_{\mathrm{G}}$ 480/270 $\mathrm{kDa}$ is distributed continuously localized along the length of the axon with a number of focused clusters (Fig. 9, arrows) of the molecule $(A)$. In contrast, neurofascin (Fig. 9B) and $\operatorname{NrCAM}(C)$ are already highly clustered (arrows), with very little staining observed along the rest of the axon. Double-labeling of these sections with anti- 
$\operatorname{ankyrin}_{\mathrm{G}}$

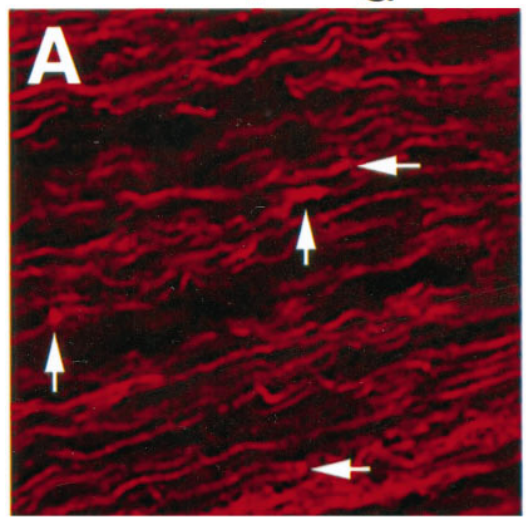

\section{ankyrin $_{\mathrm{G}} / \mathrm{MAG}$}

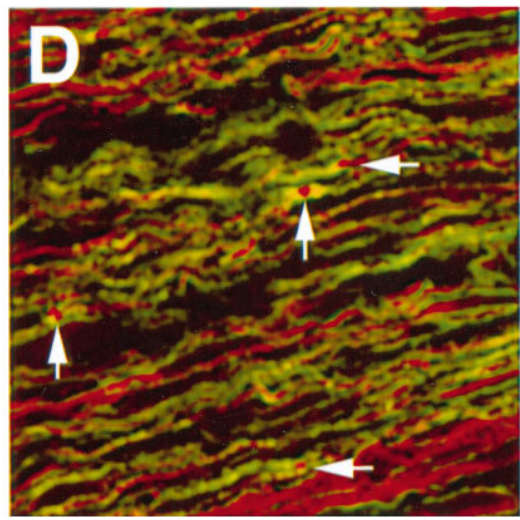

neurofascin

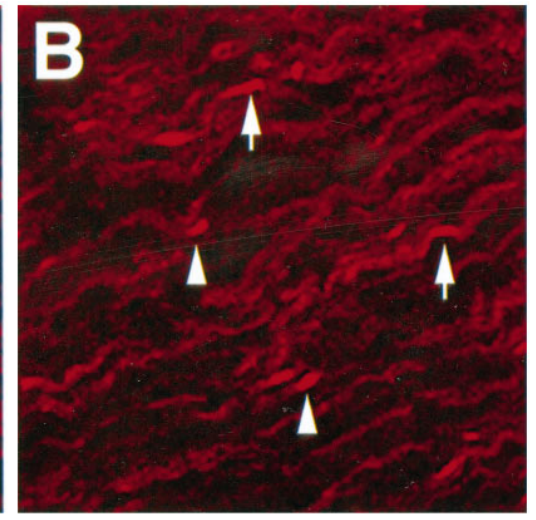

neurofascin/MAG

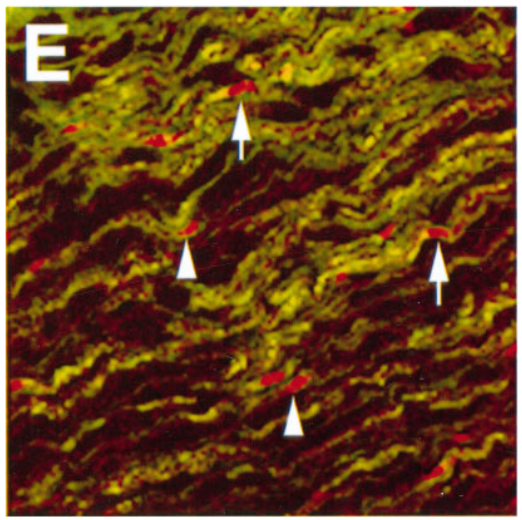

NrCAM

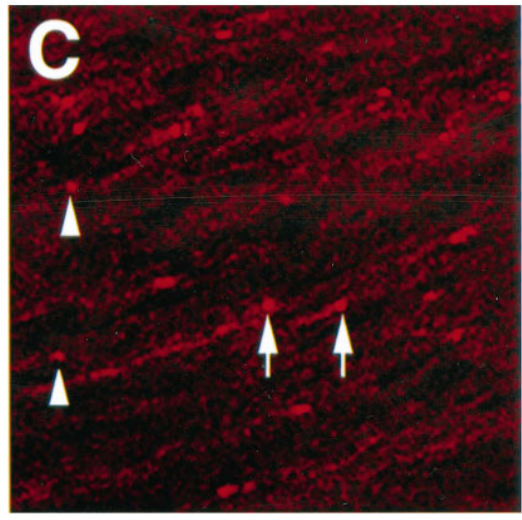

NrCAM/MAG

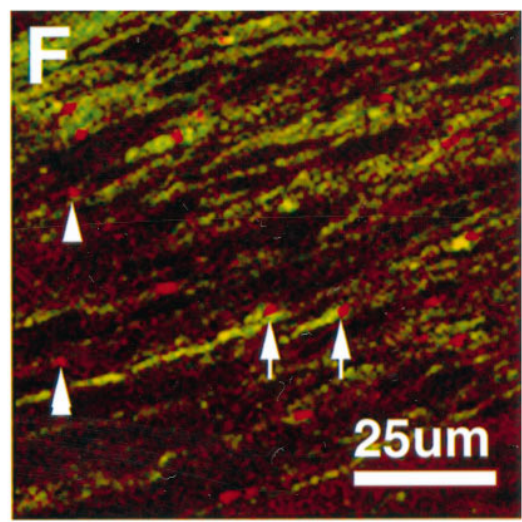

Figure 9. Distribution of ankyrin ${ }_{\mathrm{G}} 480 / 270 \mathrm{kDa}(A, D)$, neurofascin $(B, E)$, and $\operatorname{NrCAM}(C, F)$ in $4 \mu \mathrm{m}$ cryosections of the 2-d-old sciatic nerve. Also shown is the localization of these proteins with respect to MAG in the same sections $(D-F)$. Arrows denote clusters of proteins associated with MAG-positive processes; arrowheads show clusters of proteins not associated with MAG-positive processes.

bodies to MAG (Fig. 9D,E,F) shows that many of these clusters are associated with MAG-positive Schwann cells (arrows). In addition, a number of neurofascin (Fig. 9E) and NrCAM $(F)$ clusters (arrowheads) do not appear to be associated with MAG-positive Schwann cells. Similar clusters were not seen for $\operatorname{ankyrin}_{\mathrm{G}} 480 / 270 \mathrm{kDa}$. These observations suggest that the cell adhesion molecules neurofascin and NrCAM are the pioneer molecules in the assembly of clusters that subsequently contain ankyrin and the voltage-dependent sodium channel.

\section{Formation of adult nodes of Ranvier occurs by fusion of paired ankyrin ${ }_{\mathrm{G}}$-sodium channel-adhesion molecule clusters}

The presence of ankyrin and ankyrin-binding proteins in clusters early in myelination suggests that these clusters represent the initial intermediates in the assembly of a node of Ranvier. The relationship between single clusters, paired clusters, and finally mature nodes of Ranvier was analyzed by measurements of numbers of single and paired clusters and distances between paired clusters at different stages of development (Table 1). Single clusters are the predominant form at day 2 , whereas by day 5 the majority of ankyrin $_{\mathrm{G}}$ and ankyrin-binding protein clusters occur in pairs $5-10 \mu \mathrm{m}$ apart, and by day 7 very few single clusters are observed. These results suggest that the first step is formation of single clusters, with a second cluster subsequently forming at a later time. The asymmetric formation of these cluster pairs may be related to differing levels of myelination in the Schwann cells flanking the clusters. The observation of differing levels of myelination on either side of the developing node has been attributed to the partial autonomy of adjacent Schwann cells (Allt, 1969).

Measurements of distances between ankyrin clusters at different stages of development support the idea that pairs of clusters associated with adjacent Schwann cells flanking the future nodal site fuse to form the mature node of Ranvier. In the 7-d-old rat sciatic nerve a number of paired intermediates are observed that are more highly localized and closer together $(<5 \mu \mathrm{m})$ than those seen previously in the 5-d-old rat sciatic nerve. Figure 10 shows two different $4 \mu \mathrm{m}$ cryosections of the 7-d-old rat sciatic nerve labeled with antibodies to ankyrin $_{\mathrm{G}} 480 / 270 \mathrm{kDa}$. A number of different nodal intermediates are visible along with a number of mature nodes. These different structures were also stained with antibodies to NrCAM, neurofascin, and the voltage-dependent sodium channel (data not shown). Some of the intermediates in Figure 10 (arrows) have been numbered to reflect inferred stages in the formation of the node of Ranvier. Individual intermediates from each potential stage are also shown at higher magnification. These intermediates also clearly show significant staining of anky$\operatorname{rin}_{\mathrm{G}} 480 / 270$ in the cytoplasm during early stages of nodal for- 
Table 1. Tabulation of nodal intermediates stained by $\operatorname{ankyrin}_{\mathrm{G}}$ at different times during myelination of the rat sciatic nerve

\begin{tabular}{llllll}
$\begin{array}{l}\text { Postnatal } \\
\text { day }\end{array}$ & $\begin{array}{l}\text { Number of } \\
\text { nodes ob- } \\
\text { served }\end{array}$ & $\begin{array}{l}\text { Relative } \% \\
\text { of single } \\
\text { clusters }\end{array}$ & $\begin{array}{l}\text { Relative } \% \\
\text { of paired } \\
\text { clusters } \\
(5-10 \mu \mathrm{m})\end{array}$ & $\begin{array}{l}\text { Relative } \% \\
\text { of paired } \\
\text { clusters } \\
(<5 \mu \mathrm{m})\end{array}$ & $\begin{array}{l}\text { Relative \% } \\
\text { of mature } \\
\text { nodes }\end{array}$ \\
\hline 2 & 94 & 71 & 15 & 9 & 5 \\
5 & 74 & 30 & 34 & 20 & 16 \\
7 & 56 & 9 & 14 & 35 & 42
\end{tabular}

Cryosections $(4 \mu \mathrm{m})$ were prepared from the same areas of three separate sciatic nerves, at each time point, and double-stained for ankyrin $_{\mathrm{G}}$ and MAG. No significant variation in staining was noted between different nerves from the same time point. Single clusters were distinguished from mature nodes by the absence of MAG staining on one side of the cluster.

mation and a predominant membrane localization for this molecule during later stages.

\section{Formation of nodal intermediates does not require formation of compact myelin}

Peripheral myelin protein 22 (PMP-22) is expressed by myelinating Schwann cells and incorporated into compacted regions of peripheral myelin. Mutations in this gene account for the trembler phenotype in mice, characterized by peripheral nerve hypomyelination and continuous Schwann cell proliferation into adulthood (Henry and Sidman, 1988). In humans, PMP-22 mutations are responsible for Charcot-Marie-Tooth (type 1A) syndrome (Valentijn et al., 1992), which is characterized by decreased peripheral nerve conduction velocities, segmental demyelination, and partial remyelination, along with Schwann cell proliferation. To study how the inability to form compact myelin affects formation of the node of Ranvier, sciatic nerves of 20-d-old trembler mice were stained with antibodies against ankyrin $_{\mathrm{G}}$, neurofascin, and the voltage-dependent sodium channel. Figure $11 A-C$ shows the immunolocalization of these proteins in the sciatic nerves of wild-type $(++/++)$ trembler littermates. Interference contrast microscopy (DIC) shows the presence of compact myelin (Fig. 11 $A^{\prime}$ ), with mature nodes of Ranvier evident as gaps in the myelin sheath (arrows).

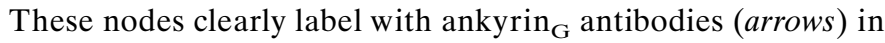
the corresponding fluorescent micrograph $(A)$. Wild-type mature nodes also label with antibodies to neurofascin (Fig. 11B) and the voltage-dependent sodium channel $(C)$. Only mature nodes were observed. In contrast, DIC micrographs of the trembler sciatic nerve $(++/$ tr) show hypomyelination (Fig. $\left.11 D^{\prime}\right)$ with an absence of clearly discernible nodal structures.

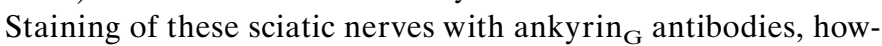
ever, shows localization of ankyrin $_{\mathrm{G}}$ to structures resembling mature nodes or potentially single-cluster intermediates (Fig. $11 D$, arrows) and to structures resembling the paired-cluster intermediates seen in developing sciatic nerves (large arrowheads). A similar staining pattern was also observed with
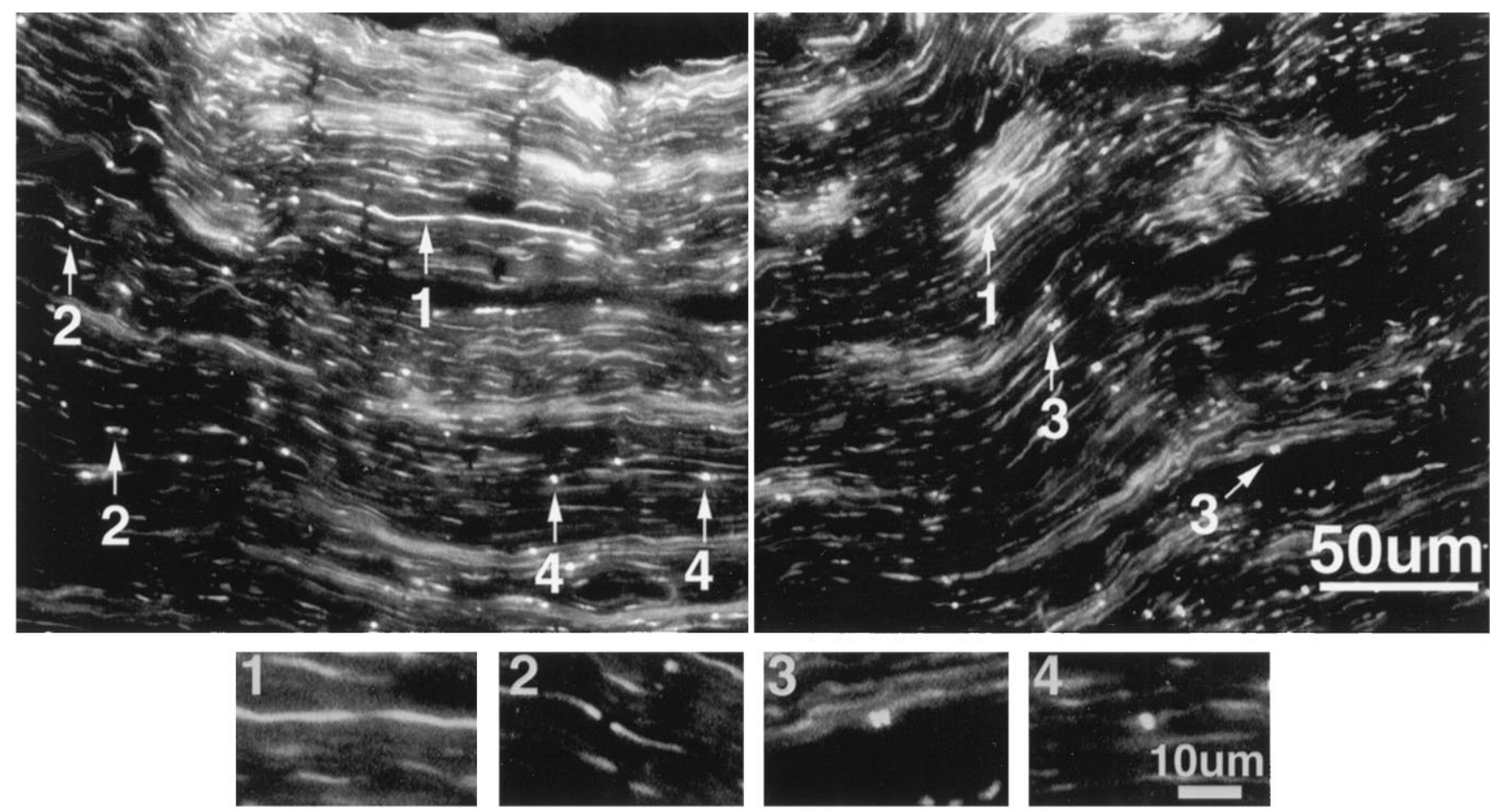

Figure 10. Immunolocalization of ankyrin $\mathrm{G}_{\mathrm{G}} 480 / 270 \mathrm{kDa}$ to nodal intermediates in the 7-d-old rat sciatic nerve. Cryosections (4 $\left.\mu \mathrm{m}\right)$ of the 7 -d-old rat sciatic nerve were labeled with antibodies to ankyrin ${ }_{\mathrm{G}} 480 / 270 \mathrm{kDa}$. Arrows indicate nodal intermediates and are numbered to indicate progressive stages in node formation. Individual nodes from each potential intermediate stage are shown below at higher magnification. 



Figure 11. Immunolocalization of ankyrin $\mathrm{G}_{\mathrm{G}} 480 / 270 \mathrm{kDa}$, neurofascin, and the voltage-dependent sodium channel in sciatic nerves from the hypomyelinated mutant mouse trembler. Cryosections $(4 \mu \mathrm{m})$ of sciatic nerves from 20-d-old wild-type $(A-C)$ and trembler $(D-F)$ mice were stained with antibodies against ankyrin ${ }_{\mathrm{G}} 480 / 270 \mathrm{kDa}(A, D)$, neurofascin $(B, E)$, and the voltage-dependent sodium channel $(C, F)$. Nodes of Ranvier are highlighted by arrows. Large arrowheads indicate double-cluster structures in the trembler mutant similar to the nodal intermediates observed in the rat developing sciatic nerve. $A^{\prime}$ and $D^{\prime}$ represent the corresponding DIC images of the immunofluorescent micrographs shown in $A$ and $D$ and illustrate the lack of

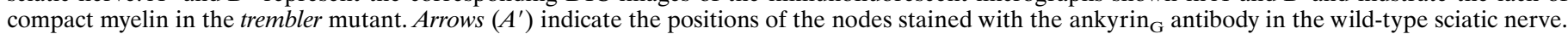

antibodies to neurofascin (Fig. 11E) and the voltagedependent sodium channel $(F)$.

\section{DISCUSSION}

Ankyrin $_{\mathrm{G}} 480 / 270 \mathrm{kDa}$ and the three ankyrin-binding integral membrane proteins neurofascin, $\mathrm{NrCAM}$, and the voltagedependent sodium channel colocalize at the axonal membrane of the adult node of Ranvier in a specialized membrane domain within the spectrin-actin network (Kordeli et al., 1995; Davis et al., 1996) (Fig. 2). Before myelination, ankyrin ${ }_{\mathrm{G}} 480 / 270 \mathrm{kDa}$ and the related ankyrin isoform ankyrin ${ }_{B} 440 \mathrm{kDa}$ are co-expressed along with $\mathrm{NrCAM}$ in an abundant, continuous distribution along the length of axons, whereas neurofascin and the voltagedependent sodium channel are present at barely detectable levels (Figs. 3, 4). This study has resolved morphological intermediates in the developmental transition from a continuous distribution of ankyrin $_{\mathrm{G}} 480 / 270 \mathrm{kDa}$ in all axons to a highly polarized localization at the node of Ranvier. The first detected event is formation of clusters containing the cell adhesion molecules neurofascin and NrCAM at sites independent of MAG-staining Schwann cell processes. Subsequent steps involve recruitment of ankyrin ${ }_{G} 480 /$ $270 \mathrm{kDa}$ and the voltage-dependent sodium channel to cluster sites defined by the cell adhesion molecules, and elaboration of MAG-staining Schwann cell processes adjacent to these cluster sites. Single clusters with associated Schwann cell processes then are joined by another cluster-MAG-staining Schwann cell process to form a pair, and pairs of clusters then fuse to form the mature node of Ranvier. In addition to rearrangements of ankyrins, differences in expression of ankyrins also occur during myelination: ankyrin $_{\mathrm{B}} 440 \mathrm{kDa}$ is downregulated from myelinating axons soon after expression of MAG and is retained in unmyelinated axons, whereas ankyrin ${ }_{\mathrm{G}} 480 / 270 \mathrm{kDa}$ disappears from unmyelinated axons.

Ankyrin $_{\mathrm{G}}$ is a candidate to couple cell adhesion molecules to the voltage-sensitive sodium channel during assembly of the node of Ranvier. This idea is supported by observations that clusters of neurofascin and $\mathrm{NrCAM}$ are joined by ankyrin $\mathrm{G}_{\mathrm{G}} 480 / 270 \mathrm{kDa}$ and the voltage-dependent sodium channel during differentiation of myelinated axons, and biochemical data that suggest a multivalent ankyrin membrane-binding domain (Michaely and Bennett, 1995a,b). The proposed ankyrin $_{\mathrm{G}}$-mediated link between adhesion molecules and ion channels would allow the cell adhesion molecules to direct the localization of voltage-sensitive sodium channels in the axonal membrane. Additional interactions of adhesion molecules with the voltage-dependent sodium channel also are likely to occur. For example, the $\beta-2$ subunit of the voltage-dependent sodium channel has homology to the NrCAMbinding protein $\mathrm{F} 11$ and potentially could also associate laterally with NrCAM (Isom et al., 1995).

The observations of this study of early and synchronous clustering of ankyrin and the voltage-dependent sodium channel during differentiation of myelinated axons disagree with the report that clustering of the sodium channel precedes that of ankyrin in neuronal-Schwann cell co-cultures (Joe and Angelides, 1992). This contradiction may result from differences in in vivo development versus in vitro cultures. Alternatively, ankyrin antibodies used in the earlier study may not distinguish between ankyrin $_{\mathrm{G}} 480 / 270 \mathrm{kDa}$ and ankyrin ${ }_{\mathrm{B}} 440 \mathrm{kDa}$, both of which colocalize to premyelinated axons (Fig. 3). The proposal of this study that formation of the node of Ranvier results from the "fusion" of two cluster intermediates composed of ankyrin, the sodium channel, and the cell adhesion molecules is in agreement with the observations of Shrager and colleagues, who have reported sodium channel clusters in single fibers from remyelinating (Dugandzija-Novakovic et al., 1995) and myelinating (Vabnick et al., 1996) sciatic nerve axons.

Clustering of neurofascin and $\mathrm{NrCAM}$ could facilitate the subsequent recruitment and enhance the local concentration of ankyrin $_{\mathrm{G}}$ and the sodium channel by several mechanisms. The ankyrin membrane-binding domain contains two binding sites for neurofascin as well as additional sites for the anion exchanger 
(Michaely and Bennett, 1995a,b) and potentially could bind preferentially to dimers or higher oligomers of neurofascin. A second manner in which the clustering of neurofascin and NrCAM might affect binding of ankyrin is through changes in intracellular signaling pathways. For example, tyrosine phosphorylation of neurofascin completely abolishes its ability to bind to ankyrin (Garver et al., 1997), and local activation of a tyrosine phosphatase could lead to recovery of neurofascin-ankyrin binding. In support of these ideas, Dubreuil et al., (1996) demonstrated recently that concentration of neuroglian, a Drosophila homolog of L1, at sites of cell-cell contact is accompanied by recruitment of Drosophila ankyrin in insect cells.

Recently, Ellisman and colleagues (Deerinck et al., 1997) observed that aggregates of ankyrin and the voltage-dependent sodium channel form in regions of nerves of dystrophic mice that lack Schwann cells, demonstrating that direct Schwann cell-axon contacts are not required for clusters. These findings contrast with the results of Shrager and colleagues (DugandzijaNovakovic et al., 1995; Vabnick et al., 1996), who have demonstrated a role for the Schwann cell in the organization and positioning of sodium channel clusters. The findings of this study that clusters of neurofascin and $\mathrm{NrCAM}$ precede elaboration of MAG-staining Schwann cell processes and that ankyrin and sodium channels cluster in the trembler mutant is consistent with the idea that the axon plays an active role in initial events in myelination and node formation. A possible explanation for these conflicting results is that Schwann cells are able to induce clusters of ankyrin and ankyrin-binding proteins in the axonal membrane, which then act as cues for the correct positioning of the Schwann cell during its adherence to the axonal membrane.

Mechanisms for the induction of ankyrin and ankyrin-binding protein clusters might include the participation of secreted molecules produced by Schwann cells or possibly other cells. Barres and coworkers (Kaplan et al., 1997) have reported that oligodendrocyte-conditioned cell-free medium can rapidly initiate aggregation of sodium channel and ankyrin in axons of cultured rat retinal ganglion cells. Interestingly these clusters appear to be spaced at the correct nodal interval, suggesting that an intrinsic axonal factor might regulate nodal periodicity. An example of a potential soluble factor is agrin, which is an extracellular matrix protein expressed by Schwann cells as well as other cells, including motor neurons (Ruegg et al., 1992). Agrin induces sodium channel clustering on cultured muscle fibers (Sharp and Caldwell, 1996) and is localized at nodes of Ranvier (Reist et al., 1987).

This study, based on observations in the myelinating sciatic nerve and experiments with the hypomyelinating mutant trembler, presents evidence that clustering of ankyrin and the voltagedependent sodium channel precedes and does not require the elaboration of compact myelin. Differentiation of the axonal membrane before the elaboration of compact myelin has been noted in electron microscopy studies of myelinating nerves (Waxman and Foster, 1980; Wiley-Livingston and Ellisman, 1980). The localization of ankyrin and the voltage-dependent sodium channel in the trembler mutant contrasts with the localization of the shaker $\mathrm{K}^{+}$channel, which does not localize to the paranodal area in these mutants (Wang et al., 1995). A potential qualification in interpreting these results are the cycles of demyelination and remyelination that the trembler mutant exhibits, which may account for the presence of nodal intermediates in the sciatic nerves of these animals. The presence of nodal intermediates in trembler, however, could be relevant to the pathophysiology of human equivalents of this mutation, such as Charcot-Marie-Tooth (type 1A) syndrome (Valentijn et al., 1992). Formation of sodium channel clusters could still provide electrophysiological benefits compared with totally dispersed distribution and could explain the relatively mild phenotype of this disease. In this case, treatments with agents that promote clusters could provide a potential therapeutic approach to ameliorate this disease as well as other disorders of myelin, such as multiple sclerosis. A candidate for such a cluster-promoting factor is the active component of oligodendrocyte-conditioned medium that induces clustering of ankyrin and sodium channels (Kaplan et al., 1997).

The observation that ankyrin $_{\mathrm{G}}$ is confined within a specialized region of the spectrin-actin network in myelinated axons implies that the spectrin-based membrane skeleton in internodal regions of myelinated axons involves ankyrin-independent attachment proteins. Spectrin does bind directly to brain membranes lacking ankyrin (Steiner and Bennett, 1988), although the identity of these sites is not yet known. An ankyrin-based mechanism for polarity in axons differs from models for formation of basolateral domains of epithelial cells (Nelson and Veshnock, 1987). In this system, the targeted recruitment of both spectrin and ankyrin has been implicated in the polarized distribution of the $\mathrm{Na}^{+} / \mathrm{K}^{+}$ ATPase in the basolateral domain.

In conclusion, this study has used newly defined molecular components of the node of Ranvier to discriminate early developmental stages in myelination. The axonal clusters of neurofascin and NrCAM described here are the earliest stage in assembly of the node of Ranvier yet to be resolved. In addition to these findings, this work also presents a new set of questions. The basis for initial clustering of cell adhesion molecules and the role of extracellular signals versus intrinsic axonal polarity is yet to be determined. The role of axonal vesicle transport in the delivery of ankyrin $_{\mathrm{G}} 480 / 270 \mathrm{kDa}$ and the voltage-dependent sodium channel to cell adhesion molecule clusters remains to be elucidated. The negative signals that exclude MAG-staining Schwann cell processes from the nodal axon segment also are not understood. Answers to these questions may eventually contribute to detailed understanding of the cellular events in myelination and help develop effective strategies to promote remyelination in clinical settings.

\section{REFERENCES}

Allt G (1969) Ultrastructural features of the immature peripheral nerve. J Anat 105:283-293.

Bennett V, Gilligan DM (1993) The spectrin based membrane skeleton and micron scale organization of the plasma membrane. Annu Rev Cell Biol 9:27-66.

Chan W, Kordeli E, Bennett V (1993) 440kd ankyrinB, structure of the major developmentally regulated domain and selective localization in unmyelinated axons. J Cell Biol 123:1463-1473.

Chiu SY (1980) Asymmetry currents in the mammalian myelinated nerve. J Physiol (Lond) 309:499-519.

Davis JQ, Bennett V (1983) Brain spectrin. Isolation of subunits and formation of hybrids with erythrocyte spectrin subunits. J Biol Chem 258:7757-7766.

Davis JQ, Bennett V (1994) Ankyrin-binding activity shared by the neurofascin/liter1/NrCAM family of nervous system cell adhesion molecules. J Biol Chem 269:27163-27166.

Davis JQ, McLaughlin T, Bennett V (1993) Ankyrin-binding proteins related to nervous system cell adhesion molecules: candidates to provide transmembrane and intercellular connections in adult brain. J Cell Biol 121:121-133.

Davis JQ, Lambert S, Bennett V (1996) Molecular composition of the node of Ranvier: identification of ankyrin-binding cell adhesion molecules neurofascin (mucin+/third FNIII domain-) and NrCAM at nodal axon segments. J Cell Biol 135:1355-1368. 
Deerinck TJ, Levinson SR, Bennett GV, Ellisman MH (1997) Clustering of voltage-sensitive sodium channels on axons is independent of direct Schwann cell contact in the dystrophic mouse. J Neurosci 17:50805088.

Dubreuil RR, Macvicar R, Dissanayake S, Liu C, Homer D, Hortsch M (1996) Neuroglian-mediated cell adhesion induces assembly of the membrane skeleton at cell contact sites. J Cell Biol 133:647-655.

Dugandzija-Novakovic S, Koszowski AG, Levinson SR, Shrager P (1995) Re-clustering of $\mathrm{Na}^{+}$channels and node of Ranvier formation in remyelinating axons. J Neurosci 15:492-503.

Ellisman MH, Levinson SR (1982) Immunocytochemical localization of sodium channel distributions in the excitable membranes of Electrophorus electricus. Proc Natl Acad Sci USA 79:6707-6711.

Garver T, Davis J, Ren Q, Bennett V (1997) Tyrosine phosphorylation at a site highly conserved in the L1 family of cell adhesion molecules abolishes ankyrin-binding and increases lateral mobility of neurofascin. J Cell Biol 137:703-714.

Henry EW, Sidman RL (1988) Long lives for homozygous trembler mutant mice despite virtual absence of peripheral nerve myelin. Science 241:344-346.

Hortsch M (1996) The L1 family of neural cell adhesion molecules: old proteins performing new tricks. Neuron 17:587-593.

Ichimura T, Ellisman MH (1991) Three-dimensional fine structure of cytoskeletal-membrane interactions at nodes of Ranvier. J Neurocytol 20:667-681.

Isom LL, Ragsdale DS, DeJongh K, Westenboek RE, Reber BF, Scheuer T, Catterall WA (1995) Structure and function of the beta-2 subunit of brain sodium channels, a transmembrane glycoprotein with a CAM motif. Cell 83:433-442.

Joe E-H, Angelides K (1992) Clustering of voltage-dependent sodium channels depends on Schwann cell contacts. Nature 356:333-335.

Kaplan MR, Meyer-Franke A, Lambert S, Bennett V, Duncan ID, Levinson SR, Barres BA (1997) Induction of sodium channel clustering by oligodendrocytes. Nature 386:724-728.

Kayyem JF, Roman J, de la Rosa E, Schwarz U, Dreyer W (1992) Bravo/NrCAM is closely related to the cell adhesion molecules 11 and $\mathrm{NgCAM}$ and has a similar heterodimer structure. J Cell Biol 118:1259-1270.

Kordeli E, Davis J, Trapp B, Bennett V (1990) An isoform of ankyrin is localized at nodes of Ranvier in myelinated axons of central and peripheral nerves. J Cell Biol 110:1341-1352.

Kordeli E, Lambert S, Bennett V (1995) Ankyrin ${ }_{\mathrm{G}}$ : a new ankyrin gene with neural specific isoforms localized at the axonal initial segment and node of Ranvier. J Biol Chem 270:2352-2359.

Kunimoto M, Otto E, Bennett V (1991) A new $440 \mathrm{kDa}$ isoform is the major ankyrin in neonatal rat brain. J Cell Biol 115:1319-1331.

Lambert S, Bennett V (1993) Anemia to cerebellar dysfunction: a review of the ankyrin gene family. Eur J Biochem 211:1-6.

Martini R, Shachner M (1986) Immunoelectron microscopic localization of neural cell adhesion molecules (L1, N-CAM and MAG) and their shared carbohydrate epitope and myelin basic protein in developing sciatic nerve. J Cell Biol 103:2439-2448.

Michaely P, Bennett V (1995a) The ANK repeats of erythrocyte ankyrin form two distinct but cooperative binding sites for the erythrocyte anion exchanger. J Biol Chem 270:31298-31302.

Michaely P, Bennett V (1995b) Mechanism for binding site diversity on ankyrin: comparison of binding sites on ankyrin for neurofascin and the $\mathrm{Cl}^{-} / \mathrm{HCO}_{3}{ }^{-}$anion exchanger. J Biol Chem 270:31298-31302.
Mocosco LM, Sanes JR (1995) Expression of four Ig superfamily adhesion molecules (L1, NrCAM/Bravo, Neurofascin/ABGP and N-CAM) in the developing mouse spinal cord. J Comp Neurol 352:321-334.

Nelson WJ, Veshnock PJ (1987) Ankyrin-binding to $\left(\mathrm{Na}^{+} / \mathrm{K}^{+}\right)$ATPase and implications for the organization of membrane domains in polarized cells. Nature 328:533-536.

Noda M, Ikeda T, Kayano T, Suzuki H, Takeshima H, Kurasaki M, Takahashi H, Numa S (1986) Existence of distinct sodium channel messenger RNAs in rat brain. Nature 320:188-192.

Peters A (1966) The node of Ranvier in the central nervous system. Q J Exp Physiol Cognit Med Sci 51:229-236.

Reist NE, Magill C, McMahan UJ (1987) Agrin-like molecules at synaptic sites in normal, denervated and damaged skeletal muscle. J Cell Biol 105:2457-2469.

Ritchie JM, Rogart RB (1977) Density of sodium channels in mammalian myelinated nerve fibers and nature of the axonal membrane under the myelinated sheath. Proc Natl Acad Sci USA 74:211-215.

Ruegg MA, Tsien KW, Horton SE, Kroger S, Escher G, Gensch EM, McMahan UJ (1992) The agrin gene codes for a family of basal laminal proteins that differ in function and distribution. Neuron 8:691-699.

Rushton WAH (1951) A theory of the effects of fibre size in medullated nerve. J Physiol (Lond) 115:101-122.

Sharp AA, Caldwell JH (1996) Aggregation of sodium channels induced by a postnatally upregulated isoform of agrin. J Neurosci 16:6775-6783.

Shrager P (1989) Sodium channels in single demyelinated axons. Brain Res 483:149-154.

Srinivasan Y, Elmer L, Davis J, Bennett V, Angelides K (1988) Ankyrin and spectrin associate with voltage-dependent sodium channels in brain. Nature 333:177-180.

Steiner JP, Bennett V (1988) Ankyrin-independent membrane proteinbinding sites for brain and erythrocyte spectrin. J Biol Chem 263:14417-14425.

Trapp BD, Andrews SB, Wong A, O'Connell M, Griffin JW (1989) Co-localization of the myelin-associated glycoprotein and the microfilament components F-actin and spectrin, in Schwann cells of myelinated nerve fibers. J Neurocytol 18:47-60.

Vabnick I, Novakovic SD, Levinson SR, Schachner M, Shrager P (1996) The clustering of axonal sodium channels during development of the peripheral nervous system. J Neurosci 16:4914-4922.

Valentijn LJ, Baas F, Wolterman RA, Hoogendijk JE, van den Bosch NH, Zorn I, Gabreels-Festen AW, de Visser M, Bolhuis PA (1992) Identical point mutations of PMP-22 in trembler-J mouse and CharcotMarie-Tooth disease type 1A. Nat Genet 2:288-291.

Wang H, Allen ML, Grigg JJ, Noebels JL, Tempel BL (1995) Hypomyelination alters $\mathrm{K}^{+}$channel expression in mouse mutants shiverer and trembler. Neuron 15:1337-1347.

Waxman SG, Foster RE (1980) Development of the axon membrane during differentiation of myelinated fibres in spinal nerve roots. Proc $\mathrm{R}$ Soc Lond [Biol] 209:441-446.

Wiley-Livingston CA, Ellisman MH (1980) Development of axonal membrane specializations defines nodes of Ranvier and precedes Schwann cell myelin elaboration. Dev Biol 79:334-355.

Zhang X, Bennett V (1996) Identification of O-linked $N$-acetyl glucosamine modification of isoforms of ankyrin targeted to nodes of Ranvier. J Biol Chem 271:31391-31398. 